\title{
Introduction
}

\section{Managing drought risk in a changing climate}

\author{
Donald A. Wilhite \\ University of Nebraska, Lincoln, NE 68583, USA
}

\begin{abstract}
There is an increasing concern worldwide regarding the ineffectiveness of current drought management practices that are based largely on crisis management. These practices are reactive and, therefore, only treat the symptoms (impacts) of drought rather than the underlying causes of the vulnerabilities associated with impacts. More effective drought management requires a shift in the paradigm from drought response to a drought risk management approach.
\end{abstract}

KEY WORDS: Drought management - Drought risk reduction - Drought policy $\cdot$ Drought early warning systems

\section{Drought impact and responses}

Drought is a naturally occurring event that occurs in virtually all of the world's climatic regimes. Drought results in significant economic, social, and environmental impacts in both developing and developed countries (Wilhite 2000, WMO 2006). Characteristics of drought impacts differ markedly from country to country and even within a country, depending on the primary economic activities and the vulnerability of the population to extended periods of water shortage (Sivakumar et al. 2014). Societal vulnerability to drought changes in response to increasing population, regional shifts of population, changes in land use, urbanization, and applications of new technology (Wilhite \& Buchanan-Smith 2005). Changes in the frequency, severity, and duration of drought will also affect drought impacts, not only by increasing the magnitude of drought impacts, but also by potentially shortening recovery time between severe drought episodes.

People most closely associate the impacts of drought with the agricultural sector because of its direct effects on plant growth, water availability and food supplies. Certainly, the agricultural sector remains one of the most vulnerable to an extended period of precipitation deficiency in Central Europe and for most other drought-prone regions (Sivaku-

\footnotetext{
${ }^{*}$ Corresponding author: dwilhite2@unl.edu
}

mar et al. 2011). Rain-fed agriculture is particularly at risk to drought. However, irrigated agriculture also experiences significant impacts if drought conditions extend over a longer period of time through reduction of available water supplies from both surface and ground water sources (Sivakumar et al. 2011). Higher temperatures, often occurring during drought episodes (Wilhite \& Glantz 1985), increase evaporative demand for water which can exceed the capacity of agricultural irrigation systems to meet this demand. In developing countries, droughts can be especially devastating since reduced agricultural productivity may raise serious food security and other public health concerns (Wilhite et al. 2014). However, the impact of today's droughts both in Central Europe and globally are more complex and often also affect many other sectors besides agriculture. Most notable are drought impacts on transportation, energy production, tourism and recreation, ecosystem services, and health, as well as broader environmental and social impacts. Drought often results in an increased level of conflict between the various water use sectors (e.g. agriculture, recreation and tourism, transportation, energy production, ecosystems) (Wilhite \& Buchanan-Smith 2005). These drought impacts occur in many countries each year, although how each country is affected by drought depends on the severity of the drought, its duration

(C) The authors 2016. Open Access under Creative Commons by Attribution Licence. Use, distribution and reproduction are unrestricted. Authors and original publication must be credited. 
and spatial extent, the level of vulnerability of key sectors and the institutional capacity of each nation in terms of both their level of preparedness and response capability (WMO \& GWP 2014). Thus, it is critical for all countries to develop national drought policies that focus on managing the risks associated with drought rather than the traditional approach of managing the disaster (i.e. crisis management). Drought risk reduction builds institutional capacity that will reduce the impacts of future drought episodes.

\section{Moving towards drought risk management}

Globally, there are serious concerns about the spiraling impacts of drought on a growing number of sectors (e.g. energy, agriculture, transportation, recreation and tourism), especially given current increases in drought incidences for many regions, and projected further increases in drought and other extreme climatic events as a result of climate change (Peterson et al. 2013, Herring et al. 2014, IPCC 2014, Melillo et al. 2014, Trenberth et al. 2015). These concerns have resulted in increased attention to the need for risk-based national drought policies and preparedness plans as an instrument to implement those policies. The need for a more proactive approach to drought management was a motivating factor that led the World Meteorological Organization's (WMO) Congress at its Sixteenth Session (held in Geneva in 2011) to recommend the organization of a 'Highlevel Meeting on National Drought Policy (HMNDP)'. Accordingly, the WMO, the Secretariat of the United Nations Convention to Combat Desertification (UNCCD), and the Food and Agriculture Organization of the United Nations (FAO), in collaboration with a number of UN agencies, international and regional organizations, and key national agencies, organized the HMNDP in Geneva in March 2013 (Sivakumar et al. 2014, Wilhite et al. 2014). The theme of HMNDP was 'Reducing societal vulnerability-helping society (communities and sectors)' (WMO 2013). This meeting aimed to encourage all countries to adopt national drought policies that focus on risk reduction by providing a framework for policy development and adoption. The meeting concluded with the unanimous approval of a declaration by the 87 attending countries that promotes the development of national drought management policies for all countries (WMO 2013).

National drought policies will establish a clear set of principles or operating guidelines to govern the management of drought and its impacts (WMO \&
GWP 2014). The overriding principle of drought policies is an emphasis on risk management through the application of preparedness and mitigation measures. These policies should be directed toward reducing risks by developing more awareness and better understanding of drought hazards and the underlying causes of societal vulnerability. The objectives associated with national drought policies will vary from country to country but, in principle, will likely reflect some common themes. The intent of the HMNDP was not to be prescriptive to countries on the specific process and elements for the development of a national drought policy, but rather to provide guidelines that would assist them in the policy development process. The 3 objectives to consider as part of a national drought policy are: (1) encourage vulnerable economic sectors and population groups to adopt self-reliant measures that promote risk management; (2) promote sustainable use of the agricultural and natural resources; and (3) facilitate early recovery from drought through actions consistent with the national drought policy objectives, i.e. risk reduction.

One of the important outcomes of the HMNDP is the continued collaboration between WMO, FAO, UNCCD and UN-Water on drought risk reduction, and agreement between these agencies on a common approach for improving drought management at the national level. This approach requires attention to 3 key pillars for drought management as part of a national drought policy development process: (1) monitoring, early warning and information delivery; (2) assessment of risk, vulnerability and impacts; and (3) mitigation and response (WMO \& GWP 2014). The crisis management approach that has historically characterized responses to drought throughout the world has not emphasized this overarching concept of drought management policy. As a result, the crisis management approach has been characterized by untimely, poorly coordinated, ineffective and costly response actions by governments and donor organizations (Wilhite et al. 2005, WMO \& GWP 2014).

\section{Drought risk management: the 3 pillars}

Drought is a slow-onset, creeping phenomenon. Thus, in the absence of a comprehensive, integrated early warning system that gathers and assesses the status of the water supplies in the hydrologic system on a regular basis, the severity of droughts often goes undetected until the water shortage reaches crisis stage for many sectors. Once a region has reached a 
state of crisis, there are few alternatives other than providing relief (e.g. forage for livestock, food aid, water) to the most drought-affected sectors. Nations need to establish an integrated drought monitoring and early warning system (pillar 1) that compiles information on the status of all segments of the hydrologic cycle and delivers that information to decision makers at all levels in a timely fashion so risks can be mitigated and reduced. This integrated monitoring system would include not only information on precipitation deficiencies and temperature anomalies but also the status of ground and surface water supplies, soil moisture, snowpack, and vegetation status among other variables. Long-term climate forecasts, although not highly reliable for many regions, may provide usable information for decision makers as well, especially for those areas where there are strong connections to phenomena such as El Niño and La Niña that result in significant climatic anomalies for many regions of the world (National Drought Mitigation Center 2016) as we have seen in 2015 and 2016. Documenting drought impacts at the local level is important to verify the severity of droughts and to identify those individuals, sectors, and communities most at risk. This information is a critical and integral component of the second and third pillars for drought management and risk reduction.

The second pillar focuses on the completion of an assessment of drought vulnerability or risk to the different sectors, population groups and regions. Vulnerability refers to the degree of resilience to drought in a society or its ability to withstand the effects of a drought episode. It is associated with the diminished capacity of an individual or group to anticipate, cope with, resist, and recover from the impacts of drought. It is also important to note that vulnerability is dynamic - as society changes, so does vulnerability to drought. The purpose of a drought vulnerability or risk assessment is to determine who and what is at risk and why (Wilhite et al. 2005, WMO \& GWP 2014).

The third and final pillar in the development of a risk-based drought management policy is the development of mitigation and response measures and options. Mitigation refers to proactive measures that are identified and implemented that increase the resilience of an individual, population group, community or nation and, thus, reduce or eliminate the negative impacts of drought. Nations cannot be 'drought-proofed' since drought is a naturally occurring phenomenon. However, the impacts of drought can be reduced or even eliminated with careful planning at all levels. The identification of mitigation measures is derived from the risk/vulnerability assessment process (pillar 2). Once identified, these mitigation measures are prioritized and implemented during this stage of the drought preparedness plan development. Response measures must support the principles of risk reduction.

\section{Drought in Central Europe-from drought response to preparedness}

I have had the pleasure of working with Mirek Trnka and his colleagues from the Czech Republic and other Central European countries for more than a decade on drought and drought management in the region. This CR Special is the culmination of much of this work, and incorporates some of the collaborative activities with the National Drought Mitigation Center at the University of Nebraska and elsewhere in the United States. Brázdil and colleagues explore incidences and causes of droughts in the Czech Republic and the Central European region over a $>500$ yr record in order to better understand the drought history of the region (Brázdil et al. 2016a). Brázdil et al. (2016b) and Trnka et al. (2016a) investigate more recent trends in drought occurrence whereas Štěpánek et al. (2016) analyze the future of drought under a changing climate. This CR Special contribution presents projections of drought-inducing climate conditions in the Czech Republic, providing a glimpse into the future and a basis for future drought management efforts (Štěpánek et al. 2016). Other contributions in this CR Special examine the relationships between drought and tree growth (Dobrovolný et al. 2016), its impact on grapes (Možný et al. 2016), and winter wheat and spring barley (Anderson et al. 2016). The interrelationships between drought, soil erosion and local flooding on agricultural lands in the Czech Republic provides yet another and important description of the complexities of drought and its impacts on agriculture (Trnka et al. 2016b). Trnka et al. (2016c) explore the changing regional weather-crop yield relationships across Europe in recent decades. This contribution gives the reader an improved understanding of the relationships between climate variability and crop yields, and provides a window for interpreting how these relationships may change in a changing climate (Trnka et al. 2016b). The contribution of Finnessey et al. (2016) is especially important given its focus on drought preparedness and the importance of timely and reliable information for decision makers at all levels as they seek to improve drought management. 
This CR Special is focused on understanding the drought hazard for Central Europe (past, present and future) and the steps necessary to improve drought assessment, response and preparedness. Drought has been and continues to be a serious threat to Central Europe and is projected to become a greater problem in future decades as a result of climate change. Coupled with the projected increase in frequency of drought episodes in the future is the increase in societal vulnerability to drought and other natural hazards, as competition for finite water supplies between different sectors continues to increase.

The contributions to this CR Special provide the underpinnings for understanding drought occurrence, its impacts and risks, and how climate information can be applied in drought planning in Central Europe. This understanding can provide the basis for further research and institutional capacity building at the national or sub-national level within the region to increase the resilience of the region to future drought episodes. In light of documented changes in climate to date and future projected changes, the time to create more drought resilient societies is now.

\section{LITERATURE CITED}

Anderson MC, Hain CR, Jurecka F, Trnka M and others (2016) Relationships between the evaporative stress index and winter wheat and spring barley yield anomalies in the Czech Republic. Clim Res 70:215-230

Brázdil R, Dobrovonlý P, Trnka M, Büntgen U and others (2016a) Documentary and instrumental-based drought indices for the Czech Lands back to AD 1501. Clim Res 70:103-117

Brázdil R, Raška P, Trnka M, Zahradníček P and others (2016b) The Central European drought of 1947: causes and consequences, with particular reference to the Czech Lands. Clim Res 70:161-178

> Dobrovolný P, Rybníček M, Büntgen U, Trnka M and others (2016) Recent growth coherence in long-term oak (Quercus spp.) ring width chronologies in the Czech Republic. Clim Res 70:133-141

Finnessey T, Hayes M, Lukas J, Svoboda M (2016) Using climate information for drought planning. Clim Res 70: 251-263

Herring SC, Hoerling MP, Peterson TC, Stott PA (eds) (2014) Explaining extreme events of 2013 from a climate perspective. Bull Am Meteorol Soc 95:S1-S96

IPCC (Intergovernmental Panel on Climate Change) (2014) Summary for policymakers. In: Climate change 2014: mitigation of climate change. Contribution of Working Group III to the fifth assessment report of the Intergovernmental Panel on Climate Change. Cambridge University Press, Cambridge

Melillo JM, Richmond TC, Yohe GW (eds) (2014) Climate change impacts in the United States: the third national climate assessment. U.S. Global Change Research Program, Washington, DC

Možný M, Brázdil R, Dobrovolný P, Trnka M and others
(2016) Drought reconstruction based on grape harvest dates for the Czech Lands, 1499-2012. Clim Res 70: 119-132

National Drought Mitigation Center (2016) ENSO and drought forecasting. http://drought.unl.edu/droughtbasics/ensoandforecasting.aspx (accessed 31 August 2016)

Peterson TC, Stott PA, Herring S (2013) Explaining extreme events of 2012 from a climate perspective. Bull Am Meteorol Soc 94:S1-14

Sivakumar MKV, Motha R, Wilhite D, Wood D (eds) (2011) Proceedings of an expert meeting on agricultural drought indices (Murcia, Spain, June 2010). World Meteorological Organization, Geneva

Sivakumar MVK, Stefanski R, Bazza M, Zelaya S, Wilhite D, Rocha Magalhaes A (2014) High-level meeting on national drought policy: summary and major outcomes. Weather Clim Extrem 3:126-132

Štěpánek P, Zahradníček P, Farda A, Skalák P, Trnka M, Meitner J, Rajdl K (2016) Projection of drought-inducing climate conditions in the Czech Republic according to Euro-CORDEX models. Clim Res 70:179-193

> Trenberth KE, Fasullo JT, Shepherd TG (2015) Attribution of climate extreme events. Nat Clim Change 5:725-730

Trnka M, Balek J, Štěpánek P, Zahradníček P and others (2016a) Drought trends over part of Central Europe between 1961 and 2014. Clim Res 70:143-160

Trnka M, Semerádová D, Novotný I, Dumbrovský M and others (2016b) Assessing the combined hazards of drought, soil erosion and local flooding on agricultural land: a Czech case study. Clim Res 70:231-249

Trnka M, Olesen JE, Kersebaum KC, Rötter RP and others (2016c) Changing regional weather-crop yield relationships across Europe between 1901 and 2012. Clim Res 70:195-214

Wilhite DA (ed) (2000) Drought: a global assessment. Vol 2. In: Keller AZ (ed) Hazards and disasters: a series of definitive major works. Routledge, London

Wilhite DA, Buchanan-Smith M (2005) Drought as hazard: understanding the natural and social context. In: Wilhite DA (ed) Drought and water crises: science, technology, and management issues. CRC Press, Boca Raton, FL, p 3-29

> Wilhite DA, Glantz MH (1985) Understanding the drought phenomenon: the role of definitions. Water Int 10: 111-120

Wilhite DA, Hayes MJ, Knutson CL (2005) Drought preparedness planning: building institutional capacity. In: Wilhite DA (ed) Drought and water crises: science, technology, and management issues. CRC Press, Boca Raton, FL, p 93-135

- Wilhite DA, Sivakumar MVK, Pulwarty RS (2014) Managing drought risk in a changing climate: the role of national drought policy. Weather Clim Extrem 3:4-13

WMO (2013) High-level meeting on national drought policy. www.wmo.int/pages/prog/wcp/drought/hmndp/index. php. (accessed 31 August 2016)

WMO (World Meteorological Organization) (2006) Drought monitoring and early warning: concepts, progress and future challenges. No. 1006. Geneva

WMO (World Meteorological Organization) \& GWP (Global Water Partnership) (2014) National drought policy guidelines: a template for action (D. A. Wilhite). Integrated Drought Management Programme (IDMP) tools and guidelines series 1. WMO, Geneva and GWP, Stockholm 